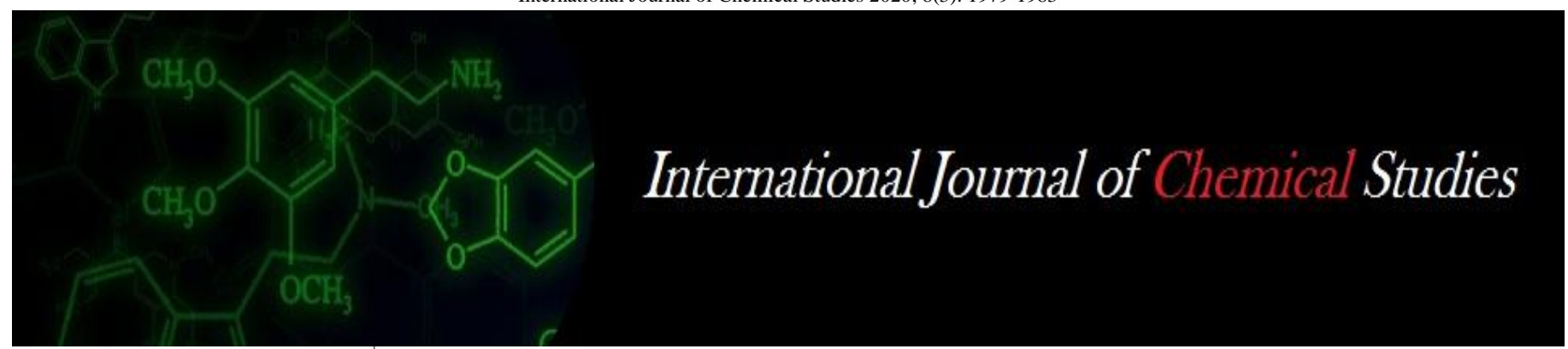

P-ISSN: 2349-8528

E-ISSN: 2321-4902

www.chemijournal.com

IJCS 2020; 8(3): 1979-1983

(C) 2020 IJCS

Received: 22-03-2020

Accepted: 25-04-2020

Yagani Sinha

Ph.D Scholar, Department of Soil Science and Agricultural Chemistry, College of

Agriculture, Indira Gandhi

Krishi Vishwavidyalaya,

Krishak Nagar, Raipur,

Chhattisgarh, India

Rajeev Srivastava

ICAR-National Bureau of Soil

Survey and Land Use Planning,

Nagpur, Maharashtra, India

Jagriti Patel

Ph.D Scholar, Department of Soil Science and Agricultural

Chemistry, College of

Agriculture, Indira Gandhi

Krishi Vishwavidyalaya,

Krishak Nagar, Raipur,

Chhattisgarh, India
Corresponding Author:

Yagani Sinha

Ph.D Scholar, Department of

Soil Science and Agricultural

Chemistry, College of

Agriculture, Indira Gandhi

Krishi Vishwavidyalaya,

Krishak Nagar, Raipur,

Chhattisgarh, India

\section{Characterization and classification of shrink- swell soils of Nagpur district, Maharashtra}

\author{
Yagani Sinha, Rajeev Srivastava and Jagriti Patel
}

DOI: https://doi.org/10.22271/chemi.2020.v8.i3aa.9495

\begin{abstract}
In the present study four representative pedons (viz. Wadhona, Kirnapur, Panjra and Karla)were selected from established shrink-swell soil series in Nagpur district of Maharashtra. The morphological, physical and chemical characteristics of soils were studied and described as per the standard procedure.All the four soil series are, in general, deep to very deep, moderately to poorly drained, rich in shrink-swell clay with the soil colour hue of 10YR and the value varying between 3 and 5 and chroma 1 and 2 . The surface soil texture was clayey in all the soil series except Wathena series which was silty clay loam. All the soils are non-saline $\left(\mathrm{EC}<0.31 \mathrm{dSm}^{-1}\right)$, surface soil $\mathrm{pH}(1: 2::$ soil: water) varies between 7.8 to 8.7 and organic carbon between 0.56 and 1.12 per cent. Free calcium carbonate found in Panjra and Karla soils varied from 1.29 to 26.72. Soil exchange complex was dominated by $\mathrm{Ca}^{2+}$ followed by $\mathrm{Mg}^{2+}, \mathrm{Na}^{+}$and $\mathrm{K}^{+}$with high CEC ranging from 34.7 to 62.6.Taxonomically, the soils of Wadhona series are classified as Typic Haplustepts, Kirnapur and Karla soils as Typic Haplusterts whereas Panjra soils qualify for Calcic Hapluterts.
\end{abstract}

Keywords: shrink-swell soils, Vertisol, Soil characterization, soil classification.

\section{Introduction}

Vertisols and Vertic intergrades occupy an area of about 257 mha globally and are mainly confined between $45^{\circ} \mathrm{N}$ and $45^{\circ} \mathrm{S}$ latitudes (Dudal, 1963) ${ }^{[3]}$. They occupy an area of 72.9 million hectares in India, constituting about 22.2 per cent of the total geographical area of the country (Murthy et al., 1982) ${ }^{[8]}$. These soils occur extensively in the state of Maharashtra and occupy 35.5 per cent of the total area of the state.

Among the 12 orders of soils recognized in Soil Taxonomy (Soil Survey Staff, 2014) [15], Vertisols are recognized by their property to shrink when dried and swell when moistened. Although, horizonation is not distinct, yet three horizons may be identified namely selfmulching surface, blocky sub-surface and wedge shaped subsoil which are related to processes of soil development (NBSS Staff, 1988). The shrink-swell soils (Vertisols) can be differentiated easily from other soil orders by the characteristic signatures reflecting dynamic morphological, physical, chemical and mineralogical properties.

Characterization of soils is fundamental to all soil studies, as it is an important tool for soil classification, which is done based on soil properties. It also provides information for understanding of the physical, chemical, mineralogical and microbiological properties of the soils (Ogunkunle, 2005). In addition it can help to determine the types of vegetation and land use best suited to a location (Globe, 2005). Soil classification, on the other hand, helps to organize our knowledge, facilitates the transferring of experience and technology from one place to another and helps to compare soil properties. A soil characterization study therefore is a major building block for understanding the soil, classifying it and getting the best understanding of the environment (Esu, 2005). Therefore shrink-swell soils of Nagpur district were selected to understand the physical and chemical which will eventually help for harnessing the potential by adopting best bet management practices in the long run. 


\section{Material and methods}

Nagpur district is located between $20^{\circ} 30^{\prime}$ to $21^{\circ} 45^{\prime} \mathrm{N}$ latitude and $78^{\circ} 15^{\prime}$ to $79^{\circ} 40^{\prime} \mathrm{E}$ longitude (Fig. 1). Physiographically, the general elevation of the district ranges between $150 \mathrm{~m}$ and $600 \mathrm{~m}$ above MSL and covering a total geographical area of 9931 sq. $\mathrm{km}$. It is classified under tropical dry sub-humid climate with a mean annual temperature of $26.8{ }^{\circ} \mathrm{C}$ and mean annual rainfall of about $1127 \mathrm{~mm}$. The soil temperature and moisture regimes are hyperthermic and ustic, respectively. The study area covers hills and ridges, very gently to gently sloping plateau, gently to moderately sloping plateau, subdued hills and valleys, piedmont alluvial plain and flood plain. However eastern and south eastern part exhibits a comparatively plain terrain with some isolated hillocks. The elevation of the terrain progressively declines from north to south.

Information about extent and distribution of different soils (series-wise) in the Nagpur district was collected from published literature/report. Using Survey of India (SOI) toposheet and available soil map (1:50,000 scale) of Nagpur district, the area was traversed for selection of sampling sites in Nagpur district. In total, four sites were selected representing dominant soil series viz. Wadhona, Kirnapur, Panjra and Karla and their detailed soil investigation was carried outfor various site and morphological characteristics like slope, stoniness etc. erosion, colour, texture, structure etc as per procedure outlined in Soil Survey Manual (Soil Survey Division Staff 2000) ${ }^{[14]}$. Horizon-wise soil samples were collected from each pedon for detailed laboratory characterization (physico-chemical properties) using standard procedures (Black 1985; Jackson, 1979) ${ }^{[2,7]}$. Particle-size distribution (texture) was determined by the International Pipette method following the procedure described by Jackson (1967) ${ }^{[6]}$. Soil $\mathrm{pH}$ was measured in soil: water suspension (1:2) by a glass electrode $\mathrm{pH}$ meter (Jackson, 1973) ${ }^{[5]}$. The clear supernatant extract obtained from the soil suspension (soil: water, 1:2) was utilized for EC measurement by conductivity bridge (Richards, 1954) ${ }^{[16]}$. Organic carbon was determined by the Walkley and Black method (Jackson, 1967) [6]. Rapid titration method was used for Calcium carbonate $\left(\mathrm{CaCO}_{3}\right)$ determination (Piper, 1966) ${ }^{[11]}$. The exchangeable bases $(\mathrm{Ca}, \mathrm{Mg}, \mathrm{K}$ and $\mathrm{Na}$ ) from non- calcareous soil were determined after extracting the soil samples by ammonium acetate $(1 \mathrm{~N} \mathrm{NH4OAc)}$ at $\mathrm{pH}$ 7.0. However, in calcareous soils, calcium and magnesium were leached by $1 N \mathrm{KCl}-$ triethanolamine buffer solution ( $\mathrm{pH}$ 8.2). The CEC of calcareous soil was determined by overnight saturating the soils with $1 N$ sodium acetate ( $\mathrm{pH} 8.2$ ) for calcareous soil and $1 N$ sodium acetate $(\mathrm{pH} 7)$ for non-calcareous soil (Jackson, 1967) ${ }^{[6]}$. Soils were classified according to Keys to Soil Taxonomy (Soil Survey Staff 2014) ${ }^{[15]}$.

\section{Result and Discussion \\ Soil morphology}

The morphological properties of four selected soils are presented in Table 1. All the four soil series soils have colour hue of 10YR. The colour value varies between 3 and 5 and chroma between 1 and 2.Soil textureas observed by feel method, was clayey except for Wadhona soils which had silt loam to silty clay loam. Soil structure, in general is medium, moderate sub-angular blocky to angular blocky except in Karla soils which is strong, medium sub-angular blocky to angular blocky. Wadhona and Panjra soils showed strong to violent effervescence with dilute $\mathrm{HCl}$. Presence of many shiny pressure faces and slickensides features were observed in sub-soils of pedons of Kirnapur, Panjra and Karla series.

Physico-chemical characteristics:

The texture of soils varied from sandy loam to clay. In general, the soils are clayey except Wadhona soils which had silt loam to silty clay loam texture. The data (Table 2) indicates that the sand, silt and clay contents varies from 8.5 24.2, $45.4-56.5$, and $23.7-40.0$ per cent respectively in Wadhona soil, 11.8 - 17.5, $27.4-38.1$, and $44.4-57.8$ per cent in Kirnapur soil, 1.1 - 5.9, 29.0 - 35.7, and $63.3-68.2$ per cent in Panjra soils and 1.0 - 7.2, 28.5 - 39.9, and 59.1 64.3 per cent, respectively in Karla soils. Relatively higher clay contents in these soils might be due to their genesis from basaltic parent material which on weathering produces high amount of clay (Eswaran et al., 1988 and Satyavathi et al., 1998) ${ }^{[4,12]}$.

Horizon-wise chemical characteristics of the soil are presented in Table 3. The data indicates that all the soils, in general, are alkaline in reaction. Surface horizon in all the soils has relatively low $\mathrm{pH}$ than sub-soils which could be due to leaching of bases from the upper layers and its deposition in the lower layers. Soil pH varies from 7.9 to 9.0 in different soils and it increases with the depth. Relatively high $\mathrm{pH}$ in Panjra soils appears due to the high sodium and magnesium contents in the soils. Electrical conductivity of soils (1:2 soil water suspensions) varied from 0.10 to $0.31 \mathrm{dSm}^{-1}$ in different soil series which indicate that the soils are non-saline. Soil organic carbon content ranged from 0.32 to $0.56 \%$ in Wadhona soils, 0.45 to $1.12 \%$ in Kirnapur soils, 0.30 to 1.01 $\%$ in Panjra soils and 0.49 to $0.59 \%$ in Karla soils. In general, the soil organic carbon (Table 3) decreased with depth (Ohta et al., 1986) ${ }^{[10]}$. Relatively higher amount of organic carbon in the surface horizon appears due to accumulation of organic matter added through crop residues. It is observed that soils of Wadhona and Kirnapur series are non-calcareous. Calcium carbonate content in Panjra and Karla soil series varied from 1.29 to 26.72 and 1.94 to 3.02 per cent, respectively. The data (Table 3) indicate that free calcium carbonate showed an irregular trend with depth in Panjra soils. This might be the result of different cycles of swelling and shrinkage which push the calcareous material to the surface and to the subsurface (Singh et al., 1994) ${ }^{[13]}$. The exchangeable bases in non-calcareous soils (Wadhona series), exchangeable calcium, magnesium, sodium and potassium ranged from 26.1 to $32.4,5.4$ to $12.6,0.30$ to 0.39 and 0.13 to $0.30 \mathrm{cmol}(\mathrm{p}+)$ $\mathrm{kg}^{-1}$, respectively whereas, in calcareous soils, exchangeable calcium, magnesium, sodium and potassium ranged from, 19.8 to $31.5,7.2$ to $15.3,0.26$ to 0.52 and 0.17 to 6.0 cmol(p+) $\mathrm{kg}^{-1}$ in Kirnapur, 19.8 to $32.4,18$ to $27,0.73$ to 1.34 and 0.30 to $0.82 \mathrm{cmol}(\mathrm{p}+) \mathrm{kg}^{-1}$ in Panjra and 41.4 to 43.2 , 16.2 to $21.6,0.43$ to 0.56 and 0.13 to $0.17 \mathrm{cmol}(\mathrm{p}+) \mathrm{kg}^{-1}$ in Karla series, respectively.Relatively high exchangeable calcium and magnesium in these soils is mainly due to their development from basaltic parent material. The CEC of Wadhona, Kirnapur, Panjra and Karla soils ranged from 34.7 to $41.7,40$ to $49.5,42.6$ to 68.6 and 58.62 to $62.6 \mathrm{cmol}(\mathrm{p}+)$ $\mathrm{kg}^{-1}$, respectively. The high CEC of black soils is attributed to the high clay content and the presence of smectite minerals (Dudal, 1963, Nimkar et al., 1992 and Balpande et al., 1996) $[3,9,1]$. Base saturation of soils of Wadhona, Kirnapur, Panjra and Karla varied from 87.02 to $107.30,62.95$ to $100.60,73.08$ to 91.36 and 98.44 to $103.14 \%$ respectively (Table 3). Relatively high base saturation in these soils is mainly due to its development from basaltic parent material. 




Fig 1: Map of the study area

Table 1: Morphological characteristics of soils

\begin{tabular}{|c|c|c|c|c|c|c|c|c|c|c|c|c|c|c|c|c|}
\hline \multirow{2}{*}{ Horizon } & \multirow{2}{*}{ Depth } & \multicolumn{2}{|c|}{ Boundary } & \multirow{2}{*}{$\begin{array}{l}\text { Matrix } \\
\text { colour }\end{array}$} & \multirow{2}{*}{ Texture } & \multirow{2}{*}{ Structure } & \multicolumn{3}{|c|}{ Consistence } & \multicolumn{2}{|c|}{\begin{tabular}{|l|} 
Porosity \\
\end{tabular}} & \multirow{2}{*}{ Nodules } & \multirow{2}{*}{ Roots } & \multirow{2}{*}{ Effervescence } & \multirow{2}{*}{$\begin{array}{c}\text { Other } \\
\text { features }\end{array}$} & \multirow[b]{2}{*}{ Additional Note } \\
\hline & & $\mathbf{D}$ & $\mathbf{T}$ & & & & $\mathbf{D}$ & $\mathbf{M}$ & $\mathbf{W}$ & $\mathbf{S}$ & Q & & & & & \\
\hline \multicolumn{17}{|c|}{ P-1 Wadhona series: Fine, smectitic, hyperthermic Typic Haplustepts } \\
\hline $\mathrm{Ap}$ & $0-18$ & $\mathrm{c}$ & $\mathrm{s}$ & \begin{tabular}{|l|l|}
$10 \mathrm{YR} 5 / 3 \mathrm{D}$ \\
\end{tabular} & sicl & m2sbk & \begin{tabular}{|l|}
$\mathrm{h}$ \\
\end{tabular} & vfi & $\mathrm{sp}$ & $\mathrm{f}$ & $\mathrm{m}$ & $4 \%$ & $\mathrm{cf}$ & es & _- & \\
\hline Bw1 & $18-38$ & c & $\mathrm{s}$ & 10YR 5/3D & sil & $\mathrm{m} 2 \mathrm{sbk}$ & $\mathrm{h}$ & vfi & $\mathrm{sp}$ & $f$ & $\mathrm{~m}$ & $10-15 \%$ & $\mathrm{cf}$ & es & $=$ & \\
\hline Bw2 & $38-68$ & $\mathrm{~g}$ & $\mathrm{~s}$ & \begin{tabular}{|l|l|}
$10 \mathrm{YR} 5 / 3 \mathrm{D}$ \\
\end{tabular} & sil & m2abk & \begin{tabular}{|l|}
$\mathrm{sh}$ \\
\end{tabular} & vfr & $\mathrm{sp}$ & $\mathrm{f}$ & $\mathrm{m}$ & $10-15 \%$ & $\mathrm{cf}$ & es & & \\
\hline $2 \mathrm{Bw} 3$ & 68-94 & $\mathrm{g}$ & $\mathrm{s}$ & \begin{tabular}{|l|l|}
$10 \mathrm{YR} 5 / 3 \mathrm{D}$ \\
\end{tabular} & sicl & m2abk & \begin{tabular}{|l|}
$\mathrm{sh}$ \\
\end{tabular} & vfr & $\mathrm{sp}$ & $\mathrm{f}$ & $\mathrm{m}$ & $3-5 \%$ & $\mathrm{cf}$ & es & - & \\
\hline 3Bw4 & $94-122$ & $\mathrm{~g}$ & $\mathrm{~s}$ & 10YR 5/3D & sicl & $\mathrm{m} 2 \mathrm{abk}$ & sh & vfr & $\mathrm{sp}$ & $\mathrm{f}$ & $\mathrm{m}$ & & & 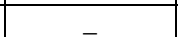 & & \\
\hline 3Bw5 & $122-150+$ & $\mathrm{g}$ & $\mathrm{s}$ & 10YR 5/3D & sicl & m2abk & $\mathrm{sh}$ & vfr & $\mathrm{sp}$ & $\mathrm{f}$ & $\mathrm{m}$ & & & & & \\
\hline \multicolumn{17}{|c|}{ P-2 Kirnapur series: Very-fine, smectitic, hyperthermic Typic Haplusterts } \\
\hline Ap & $0-13$ & c & $\mathrm{S}$ & 10YR 3/2D & $\mathrm{c}$ & $\mathrm{m} 2 \mathrm{sbk}$ & $\mathrm{h}$ & vfi & vsvp & vf & $\mathrm{m}$ & & $\mathrm{fc}$ & - & $\mathrm{pf}$ & \\
\hline $\mathrm{Bw}$ & $13-34$ & $\mathrm{~g}$ & $\mathrm{~S}$ & 10YR 3/2D & $\mathrm{c}$ & m2abk & vh & vfi & \begin{tabular}{|l|} 
vsvp \\
\end{tabular} & vf & $\mathrm{m}$ & & vff &  & iss & \\
\hline Bss1 & $34-74$ & $\mathrm{~g}$ & $\mathrm{~S}$ & \begin{tabular}{|l|l|}
$10 \mathrm{YR} 3 / 2 \mathrm{D}$ \\
\end{tabular} & $\mathrm{c}$ & m2abk & $\mathrm{h}$ & vfr & vsvp & vf & $\mathrm{m}$ & - & vff & - & iss & cracks up to \\
\hline Bss2 & $74-103$ & $\mathrm{~g}$ & $\mathrm{~S}$ & 10YR 3/2D & $\mathrm{c}$ & m2abk & $\mathrm{h}$ & vfr & \begin{tabular}{|l|} 
vsvp \\
\end{tabular} & vf & $\mathrm{m}$ & - & vf $\mathrm{f}$ & - & iss & $20 \mathrm{~cm}$ \\
\hline Bss3 & $103-128$ & $\mathrm{~g}$ & $\mathrm{~S}$ & 10YR 3/2D & $\mathrm{c}$ & m2abk & $\mathrm{h}$ & vfr & \begin{tabular}{|l|} 
vsvp \\
\end{tabular} & vf & $\mathrm{m}$ & & vff & - & iss & \\
\hline Bss4 & $128-150+$ & $\mathrm{g}$ & $\mathrm{S}$ & $10 \mathrm{YR} 3 / 2 \mathrm{D}$ & $\mathrm{c}$ & m2abk & $\mathrm{h}$ & vfr & vsvp & \begin{tabular}{|l|}
$\mathrm{vf}$ \\
\end{tabular} & $\mathrm{m}$ & & vff & & iss & \\
\hline \multicolumn{17}{|c|}{ P-3 Panjra: Very-fine, smectitic, hyperthermic calcic Haplusterts } \\
\hline $\mathrm{Ap}$ & $0-14$ & c & $\mathrm{S}$ & 10YR 3/2D & $\mathrm{c}$ & m3sbk & $\mathrm{vh}$ & vfi & vsvp & \begin{tabular}{|l|l|} 
vf \\
\end{tabular} & $\mathrm{m}$ & - & $\mathrm{cf}$ & _- & & \multirow{6}{*}{$\begin{array}{l}\text { Cracks up to } \\
55 \mathrm{~cm} \text { and } 2- \\
3 \mathrm{cmwide}\end{array}$} \\
\hline $\mathrm{Bw}$ & $14-29$ & c & $\mathrm{S}$ & \begin{tabular}{|l|} 
10YR 3/2D \\
\end{tabular} & $\mathrm{c}$ & m3sbk & vh & vfi & \begin{tabular}{|l|} 
vsvp \\
\end{tabular} & vf & $\mathrm{m}$ & \begin{tabular}{|l|}
$\mathrm{m} 1-3 \%$ \\
\end{tabular} & $\mathrm{cf}$ & $\mathrm{e}$ & & \\
\hline Bss1 & $29-68$ & $\mathrm{c}$ & $\mathrm{S}$ & \begin{tabular}{|l}
$10 Y R ~ 4 / 2 D$ \\
\end{tabular} & $\mathrm{c}$ & m2abk & vh & vfi & $\begin{array}{ll}\text { vsvp } \\
\end{array}$ & $f$ & $\mathrm{~m}$ & m 25-30\% & $\mathrm{ff}$ & ev & $\mathrm{pf}$ & \\
\hline Bss2k & $68-93$ & $\mathrm{c}$ & $\mathrm{S}$ & $10 \mathrm{YR} 4 / 2 \mathrm{D}$ & $\mathrm{c}$ & m2abk & vh & vfi & vsvp & $\mathrm{f}$ & $\mathrm{m}$ & m 25-30\% & - & $\mathrm{ev}$ & iss & \\
\hline Bss3 & $93-122$ & $\mathrm{c}$ & $\mathrm{S}$ & 10YR 3/2D & $\mathrm{c}$ & m2abk & vh & vfi & \begin{tabular}{|l|} 
vsvp \\
\end{tabular} & $\mathrm{f}$ & $\mathrm{m}$ & m 10-15\% & - & $\mathrm{ev}$ & iss & \\
\hline Bss4 & $122-150+$ & $\mathrm{c}$ & $\mathrm{S}$ & $10 \mathrm{YR} 4 / 2 \mathrm{D}$ & $\mathrm{c}$ & m2abk & vh & vfi & vsvp & $\mathrm{f}$ & $\mathrm{m}$ & m 30\% & & $\mathrm{ev}$ & iss & \\
\hline \multicolumn{17}{|c|}{ P-4 Karla series: Very-fine, smectitic (calcareous), hyperthermic Typic Haplusterts } \\
\hline $\mathrm{Ap}$ & $0-20$ & $\mathrm{c}$ & $\mathrm{S}$ & 10YR 3/2D & $\mathrm{c}$ & m3sbk & $\mathrm{vh}$ & vfi & vsvp & vf & $\mathrm{m}$ & & $\mathrm{cc}$ & & - & \\
\hline $\mathrm{Bw}$ & $20-45$ & $\mathrm{~g}$ & $\mathrm{~S}$ & 10YR 3/2D & $\mathrm{c}$ & m3sbk & vh & vfi & vsvp & vf & $\mathrm{m}$ & & $\mathrm{cc}$ & & $\mathrm{pf}$ & \\
\hline Bss & $45-69$ & $\mathrm{~g}$ & $\mathrm{~S}$ & 10YR 3/2D & $\mathrm{c}$ & m3abk & $\mathrm{vh}$ & vfr & vsvp & vf & $\mathrm{m}$ & & $\mathrm{cc}$ & _ & ss & \\
\hline
\end{tabular}

Table 2: Physical properties of soils

\begin{tabular}{|c|c|c|c|c|c|}
\hline Horizon & Depth (cm) & Texture & Sand $(\%)$ & Silt (\%) & Clay (\%) \\
\hline \multicolumn{6}{|c|}{ Wadhona series: Fine, smectitic, hyperthermic Typic Haplustepts } \\
\hline Ap & $0-18$ & sicl & 8.6 & 56.5 & 34.9 \\
\hline Bw1 & $18-38$ & sil & 24.2 & 50.6 & 25.2 \\
\hline $\mathrm{Bw} 2$ & $38-68$ & sil & 24.2 & 52.1 & 23.7 \\
\hline $2 \mathrm{Bw} 3$ & $68-94$ & sicl & 8.5 & 55.3 & 36.2 \\
\hline $3 \mathrm{Bw} 4$ & $94-122$ & sicl & 15.2 & 48.1 & 36.7 \\
\hline $3 \mathrm{Bw} 5$ & $122-150+$ & sicl & 14.6 & 45.4 & 40.0 \\
\hline \multicolumn{6}{|c|}{ Kirnapur series: Very-fine, smectitic, hyperthermic Typic Haplusterts } \\
\hline Ap & $0-13$ & $\mathrm{c}$ & 17.5 & 38.1 & 44.4 \\
\hline $\mathrm{Bw}$ & $13-34$ & $\mathrm{c}$ & 16.5 & 33.2 & 50.3 \\
\hline Bss1 & $34-74$ & $\mathrm{c}$ & 16.3 & 27.4 & 56.3 \\
\hline Bss2 & $74-103$ & $\mathrm{c}$ & 12.2 & 31.6 & 56.1 \\
\hline Bss3 & $103-128$ & $\mathrm{c}$ & 11.8 & 31.0 & 57.2 \\
\hline Bss4 & $128-150+$ & $\mathrm{c}$ & 13.4 & 28.8 & 57.8 \\
\hline
\end{tabular}




\begin{tabular}{|c|c|c|c|c|c|}
\hline \multicolumn{6}{|c|}{ Panjra series: Very-fine,smectitic,hyperthermic Calcic Haplusterts } \\
\hline Ap & $0-14$ & $\mathrm{c}$ & 1.8 & 31.7 & 66.5 \\
\hline $\mathrm{Bw}$ & $14-29$ & $\mathrm{c}$ & 1.4 & 31.5 & 67.0 \\
\hline Bss1 & $29-68$ & $\mathrm{c}$ & 5.9 & 29.0 & 65.2 \\
\hline Bss $2 k$ & $68-93$ & $\mathrm{c}$ & 2.3 & 29.5 & 68.2 \\
\hline Bss3 & 93-122 & $\mathrm{c}$ & 3.3 & 29.7 & 67.0 \\
\hline Bss4 & $122-150+$ & $\mathrm{c}$ & 1.1 & 35.7 & 63.3 \\
\hline \multicolumn{6}{|c|}{ Karla series: Very-fine, smectitic (calcareous), hyperthermic Typic Haplusterts } \\
\hline Ap & $0-20$ & $\mathrm{c}$ & 1.1 & 39.9 & 59.1 \\
\hline $\mathrm{Bw}$ & $20-45$ & $\mathrm{c}$ & 1.0 & 38.8 & 60.2 \\
\hline Bss & $45-69$ & $\mathrm{c}$ & 7.2 & 28.5 & 64.3 \\
\hline
\end{tabular}

Table 3: Chemical characteristics of soils

\begin{tabular}{|c|c|c|c|c|c|c|c|c|c|c|c|c|}
\hline \multirow{3}{*}{ Horizon } & \multirow{3}{*}{ Depth (cm) } & \multirow{3}{*}{ pH (1:2) } & \multirow{3}{*}{$\mathrm{EC}\left(\mathrm{dS} \mathrm{m}^{-1}\right)$} & \multirow{3}{*}{ OC $(\%)$} & \multirow{3}{*}{$\mathrm{CaCO}_{3}(\%)$} & \multicolumn{4}{|c|}{ Exchangeable cations } & \multirow{2}{*}{ Sum of cation } & \multirow{3}{*}{ CEC } & \multirow{3}{*}{ B.S $(\%)$} \\
\hline & & & & & & $\mathbf{C a}^{2+}$ & $\mathrm{Mg}^{2+}$ & $\mathrm{Na}^{+}$ & $\mathbf{K}^{+}$ & & & \\
\hline & & & & & & \multicolumn{5}{|c|}{ meq $100 \mathrm{~g}^{-1}$} & & \\
\hline \multicolumn{13}{|c|}{ Wadhona series:Fine, Smectic, hyperthermic Typic Haplustepts } \\
\hline Ap & $0-18$ & 7.9 & 0.17 & 0.56 & - & 26.1 & 8.1 & 0.30 & 0.30 & 34.8 & 40.0 & 87.0 \\
\hline Bw1 & $18-38$ & 8.2 & 0.12 & 0.37 & - & 28.8 & 9.9 & 0.39 & 0.17 & 39.3 & 40.0 & 98.2 \\
\hline Bw2 & $38-68$ & 8.4 & 0.12 & 0.32 & - & 27.0 & 7.2 & 0.35 & 0.13 & 34.7 & 34.8 & 99.7 \\
\hline 2Bw3 & $68-94$ & 8.4 & 0.13 & 0.41 & - & 26.1 & 12.6 & 0.35 & 0.17 & 39.2 & \begin{tabular}{|l|}
40.9 \\
\end{tabular} & 96.0 \\
\hline 3Bw4 & $94-122$ & 8.2 & 0.13 & 0.36 & - & 31.5 & 8.1 & 0.35 & 0.17 & 40.1 & 37.4 & 107.3 \\
\hline 3Bw5 & $122-150+$ & 8.4 & 0.15 & 0.36 & - & 32.4 & 5.4 & 0.35 & 0.17 & 38.3 & 41.7 & 91.8 \\
\hline \multicolumn{13}{|c|}{ Kirnapur series:Very-fine, smectitic hyperthermic Typic Haplusterts } \\
\hline Ap & $0-13$ & 7.8 & 0.31 & 1.12 & - & 30.6 & 7.2 & 0.35 & 0.61 & 38.8 & 40.0 & 96.9 \\
\hline $\mathrm{Bw}$ & $13-34$ & 8.2 & 0.18 & 0.45 & - & 31.5 & 10.8 & 0.35 & 0.22 & 42.9 & 42.6 & 100.6 \\
\hline Bss1 & $34-74$ & 8.3 & 0.17 & 0.48 & - & 26.1 & 10.8 & 0.26 & 0.17 & 37.3 & 49.6 & 75.3 \\
\hline Bss2 & $74-103$ & 8.3 & 0.19 & 0.47 & - & 19.8 & 8.1 & 0.35 & 0.22 & 28.5 & 45.2 & 63.0 \\
\hline Bss3 & $103-128$ & 8.3 & 0.17 & 0.51 & - & 25.2 & 9.0 & 0.48 & 0.30 & 35.0 & \begin{tabular}{|l|}
48.7 \\
\end{tabular} & 71.8 \\
\hline Bss4 & $128-150+$ & 8.4 & 0.20 & 0.54 & - & 27.9 & 15.3 & 0.52 & 0.22 & 43.9 & 49.6 & 88.6 \\
\hline \multicolumn{13}{|c|}{ Panjra series:Very-fine,smectitic hyperermic Calcic Haplusterts } \\
\hline Ap & $0-14$ & 8.7 & 0.24 & 1.05 & 3.00 & 32.4 & 16.2 & 0.78 & 0.83 & 50.2 & 68.7 & 73.1 \\
\hline Bw1 & $14-29$ & 8.8 & 0.22 & 0.70 & 1.29 & 30.6 & 27.0 & 1.09 & 0.35 & 59.0 & 70.4 & 83.8 \\
\hline Bss1 & $29-68$ & 8.9 & 0.26 & 0.48 & 14.44 & 25.2 & 25.2 & 1.35 & 0.30 & 52.1 & 57.4 & 90.7 \\
\hline Bss2k & $68-93$ & 9.0 & 0.27 & 0.30 & 26.72 & 19.8 & 19.8 & 1.00 & 0.30 & 40.9 & 47.0 & 87.1 \\
\hline Bss3 & $93-122$ & 8.7 & 0.26 & 0.42 & 7.51 & 25.2 & 16.2 & 0.74 & 0.35 & 42.5 & 61.7 & 68.8 \\
\hline Bss4 & $122-150+$ & 8.7 & 0.26 & 0.30 & 11.76 & 19.8 & 18.0 & 0.78 & 0.35 & 38.9 & \begin{tabular}{|l|}
42.6 \\
\end{tabular} & 91.4 \\
\hline \multicolumn{13}{|c|}{ Karla series: Very-fine,smectitic (calcareous), hyperthermic Typic Haplusterts } \\
\hline Ap & $0-20$ & 7.9 & 0.13 & 0.59 & 1.94 & 41.4 & 21.6 & 0.52 & 0.17 & 63.7 & 62.6 & 101.7 \\
\hline $\mathrm{Bw}$ & $20-45$ & 8.0 & 0.10 & 0.54 & 2.37 & 41.4 & 16.2 & 0.43 & 0.17 & 58.2 & 59.1 & 98.4 \\
\hline Bss & $45-69$ & 8.0 & 0.12 & 0.49 & 3.02 & 43.2 & 16.2 & 0.57 & 0.13 & 60.1 & 58.3 & 103.1 \\
\hline
\end{tabular}

\section{Soil Classification}

On the basis of morphology and physico-chemical characteristics of the soils and climate data, the soils were classified according to keys to Soil Taxonomy (Soil Survey Staff 2014) ${ }^{[15]}$. Wadhona soils are classified in the order Inceptisols because of the absence of any other diagnostic horizon other than cambic $(\mathrm{Bw})$ horizon. As the moisture regime is Ustic, It was classified as Ustept at sub order level and Haplustepts at great group level because other than argillic horizon these soils not having any horizon like natric horizon, petro calcic horizon, duripan and plinthite horizons. Further, this did not have vertic properties and lithic contact with in $50 \mathrm{~cm}$ from the soil surface. Hence this pedon is classified as Typic Haplustepts at sub group level. Owing to the hyperthermic moisture regime, less than $35 \%$ clay content in some horizons, wedge shaped peds with long axes and 3-5 $\mathrm{cm}$ wide cracks that open and close periodicallyhence it is classified as fine, smectitic, hyper thermic,Typic Haplustepts. Likewise Kirnapur, Panjra and Karla series are classified as Vertisols because of the presence of slickensides (Bss) in horizon. These were classified as Usterts at sub order level and were classified as Haplustertsat great group level. Pedon Kirnapur and Karla were further classified as Typic Haplustert at sub-group level but Panjra has 15 percent or more secondary accumulation of calcium carbonate in the sub-surface horizons depicting presence of calcic horizon and hence, was classified as Calcic Haplustert. These series are found in hyperthermic moisture regime with more than $35 \%$ clay content in all horizons, slickensides, wedge shaped peds with long axes and 3-5 cm wide cracks that open and close periodically, hence, Kirnapur pedon is classified as veryfine, smectitic, hyperthermic, Typic Haplustert, whereas Panjrapedon is classified as very fine, smectitic, hyper thermic, calcic Haplustert and due to the calcareous nature, Karla soils classified as 'very fine, smectitic, hyperthermic(calcareous), Typic Haplustert.

\section{Reference}

1. Balpande SS, Deshpande SB, Pal DK. Factor and process of soil degredation in Vertisols of Purna Valley, Maharashtra India. Land Degradation and Development.1996; 7:313-324.

2. Black CA. Methods of Soil Chemical Analysis, American Society of Agronomy, Madison, Wisconsin, USA. 1985, 2.

3. Dudal R. Dark clay soils of tropical and subtropical region. Soil Science. 1963; 95(4):264-270.

4. Eswaran H, Kimble J, Cook T. Properties, genesis and classification of Vertisols. In: Hirekerur LR, Pal DK, Sehgal JL, Deshpande SB (Eds), Trans. International Workshop - Classification, Management and Use 
Potential of Swell-Shrink Soils. Oxford Univ. Press and IBH, New Delhi, 1988, 1-22.

5. Jackson ML. Soil Chemical Analysis (Asian reprint of original US edn. published in 1958), Prentice Hall, New Delhi, India, 1973.

6. Jackson ML. Soil chemical analysis, Prentice Hall India Pvt. Ltd., New Delhi. India, 1967.

7. Jackson ML. Soil Chemical Analysis: Advance Course. University of Wisconsin, Madison, Wisconsin. USA, 1979.

8. Murthy RS, Bhattacharjee JC, LandeRJ, Pofali RM. Distribution, characteristics and classification of Vertisols. Trans. 12th International Congress of Soil ScienceSymposium.1982; 2:3-22.

9. Nimkar AM, Deshpande SB, Babrekar PG. Evaluation of salinity problem in shrink-swell soils of a part of Purna Valley, Maharashtra. Agropedology. 1992; 2:59-65.

10. Ohta S, Suzuki A, Kumada K. Experimental studies on the behavior of fine organic particles and water soluble organic matter in mineral soil horizons. Soil Sci. Plant Nutr. 1986; 32(1):15-26.

11. Piper CS. Soil and Plant Analysis, Hans Publications, Bombay, 1966.

12. Satyavathi PLA. Influence of structural condition of Vertisols on water retention characteristics. Journal of the Indian Society of Soil Science, 1979; 46(1):129-132.

13. Singh R, Bhargava GB, Tiwari GB. Hydraulic conductivity of some Entisols, Inceptisols and their role in soil and water management. Journal of the Indian Society of Soil Science. 1994; 44(3):341-345.

14. Soil Survey Division Staff. Soil Survey Manual (Indian print), USDA, Washington DC, 2000, 18.

15. Soil Survey Staff. Keys to Soil Taxonomy. USDA, Natural Resources Conservation Service, Washington DC, 2014, 12.

16. Richards LA. Diagnosis and improvement of saline and alkali soils (USDA Agril. Handbook No (60)), Washington, D.C, 1954. 